\title{
Molluscan assemblages in Late Holocene tufa cones in the Pieniny Mountains (southern Poland)
}

\author{
Witold Paweł ALEXANDROWICZ $Z^{1, ~ * ~}$
}

1 AGH University of Science and Technology, Faculty of Geology, Geophysics and Environment Protection, Al. A. Mickiewicza 30, 30-059 Kraków, Poland

Alexandrowicz, W.P., 2014. Molluscan assemblages in Late Holocene tufa cones in the Pieniny Mountains (southern Poland). Geological Quarterly, 58 (2): 269-280; doi: 10.7306/gq.1150

\begin{abstract}
Limestone rock walls of various inclination form a favourable substrate for the deposition of calcareous tufas that form cone-shaped structures located at the foot of slopes or fill niches within them. Such carbonate deposits usually contain rich and diversified molluscan assemblages, whose composition and structure closely correspond to the ambient environmental conditions in the immediate vicinity. The study of the Pieniny Mountains area revealed ten sites with such deposits. The identified malacofauna was subjected to detailed analysis. It enabled identification of three types of faunistic assemblages (Bythinella austriaca assemblage, Pyramidula pusilla assemblage, and a shade-loving species assemblage), which are related to the conditions prevailing during the deposition. Tufa cones found in the Pieniny Mountains represent the historic period (Late Holocene). The deposits provide a record of two climatic phases: warmer and colder. The former (Medieval Warm Period) involved the intensified deposition of carbonate material and the rapid growth of tufa cones. The latter - the Little Ice Age - entailed the slow degradation of cones and slower sedimentation of tufas, while the intensified physical weathering led to the increase in the clast material proportion (sharp-edged limestone fragments). Tufas accumulated in the zone unaffected by high anthropogenic pressure and thus represent a record of natural environmental changes during the historic period.
\end{abstract}

Key words: calcareous tufa, molluscan assemblages, historic period, Pieniny Mts., southern Poland.

\section{INTRODUCTION}

Calcareous tufas are formed as a result of calcium carbonate precipitation from water. Their formation and accumulation processes are facilitated by alterations of carbon dioxide content in calcium carbonate-rich waters. Part of $\mathrm{CO}_{2}$ dissolved in water binds to water particles and, in the form of $\mathrm{HCO}_{3}^{-}$anion, it reacts with $\mathrm{Ca}^{++}$cations, producing water-soluble acidic calcium carbonate $\left(\mathrm{Ca}\left(\mathrm{HCO}_{3}\right)_{2}\right)$. This compound is stable up to its natural solubility limit, when $\mathrm{CO}_{2}$ is in excess. The depletion of $\mathrm{CO}_{2}$ upsets the balance, thereby causing decomposition of $\mathrm{Ca}\left(\mathrm{HCO}_{3}\right)_{2}$. The product of this reaction is hardly water-soluble calcium carbonate $\left(\mathrm{CaCO}_{3}\right)$ which precipitates forming calcareous tufas. The decrease in carbon dioxide concentration in water can be caused by many factors, including physicochemical processes, such as water turbulence and temperature changes, as well as biological ones, i.e., $\mathrm{CO}_{2}$ uptake and its use by various groups of organisms for their life processes, mainly photosynthesis. The most essential role is played by bryophytes and algae. The nature of these processes and the mechanisms of calcareous tufa sedimentation have been the

\section{*E-mail:wpalex@geol.agh.edu.pl}

Received: July 10, 2013; accepted: January 13, 2014; first published online: February 20, 2014 subject of studies by numerous authors and described in many publications (e.g., Ložek, 1959, 1961, 1963, 1964; Chafetz and Folk, 1984; Pedley, 1990, 2009; Pentecost, 1991, 1995; Goudie et al., 1993; Pentecost and Viles, 1994; Alexandrowicz, 2004). Calcareous tufas are formed in different types of sedimentary environments. A widely occurring type is calcium carbonate precipitation in the immediate vicinity of springs, which usually involves encrustations and coatings on rock clasts or plants, and breccias composed of rock fragments cemented by calcium carbonate. Fine-grained and silty calcareous tufas, sometimes interlayered by peat mud and peat, are a formation characteristic of small water bodies and boggy depressions occurring in flat valley bottoms or on floodplains. Calcareous tufas are also often developed in the lower parts of slopes, where they form flat cone structures composed of coarse-grained variants with numerous blocks of compact tufas. The favourable conditions for the accumulation of these deposits are also found in stream valleys featuring only slight drops of altitude. Granular tufas dominate there, often forming terrace benches. A highly typical location of calcareous tufa is to fill small and shallow lakes emerging behind rock barriers across river valleys, as well as colluvial formations or dams. Classifications of calcareous tufa have been presented by many authors in numerous studies (e.g., Pedley, 1990, 2009; Pentecost, 1991, 1995; Goudie et al., 1993; Pentecost and Viles, 1994).

The specific form of occurrence of calcareous tufas is a tufa cone accumulating beneath vertical or overhanging rock walls (types A and B; Fig. 1), as well as adjacent to inclined rock slopes, where they fill niches and hollows (type C; Fig. 1). In wa- 


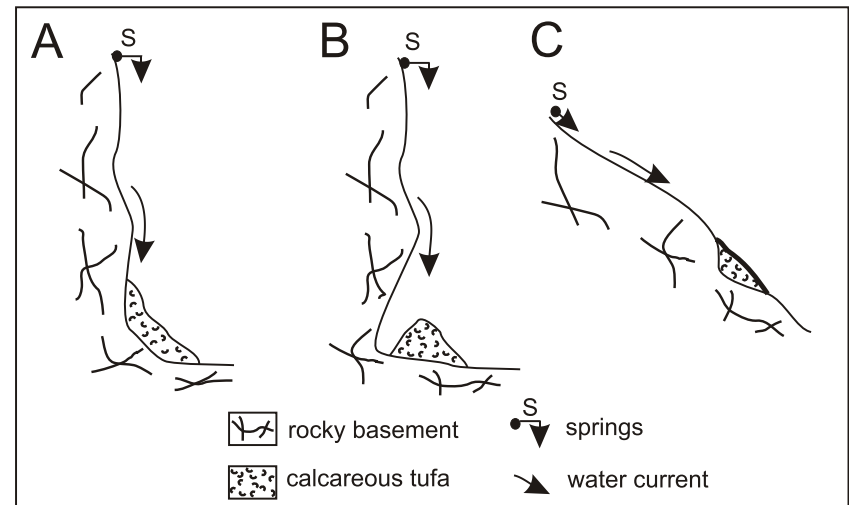

Fig. 1. Types of subhygropetric tufas cones in Pieniny Mts.

ter outflow sites and places where it dribbles down the rock, bryophytes and algae grow in abundance. In hydrobiological terminology, such habitats are known as hygropetric zones (Mikulski, 1974). They are marked by considerable temperature fluctuations, good exposure to light, and rapid water evaporation. These factors facilitate calcium carbonate precipitation. When precipitating, $\mathrm{CaCO}_{3}$ forms encrustations on rocks, which grow in thickness in the course of time and fall under their own weight, accumulating at the foot of walls or inside hollows in the form of tufa cones. They always contain scree fragments crumbling away as a result of weathering. Such cones are dominated by unconsolidated, usually fine-grained and silty tufa variants. They are sometimes referred to as subhygropetric tufas (Ložek, 1962, 1964, 1973; Alexandrowicz, 1988, 2004).

Calcareous tufas of such features and origin often contain numerous and well-preserved molluscan shells which represent malacocoenoses living on rock walls directly above the accumulating carbonate deposits. Profiles of such tufas with abundant molluscan shells have been described in the Czech Republic and Slovakia (Ložek, 1959, 1961, 1962, 1963, 1964), as well as in the Polish part of the Pieniny (Alexandrowicz et al., 1985; Alexandrowicz, 1988) and Tatra Mountains (Alexandrowicz, 1988, 2001, 2004; Gradziński et al., 2001; Smieja and Smieja-Król, 2007). Due to their low resistance to eroding factors, these sites represent almost exclusively the Late Holocene and historic period (Alexandrowicz, 1997, 2004, 2009, 2010).

The current malacofauna of the Pieniny Mountains has been the subject of numerous studies, and can be considered to have been thoroughly explored. Detailed descriptions of species and their assemblages, together with ecological coverage, can be found in extensive publications (e.g., Urbański, 1939; Riedel, 1982, 1988; Alexandrowicz, 1997), as well as more wide-ranging published material concerning the occurrence of individual species in Poland (Riedel, 1982, 1988).

Malacological research of Quaternary deposits in the Pieniny Mountains has been undertaken since the second half of the 20th century. A few tens of sites of subfossil malacofauna have been described to date in this area, which mainly represent the Late Glacial and Holocene. The results of these analyses, including origin and age, have been presented in numerous papers concerning different sites (e.g., Alexandrowicz, $1990,1993)$, as well as more extensive publications pertaining to the subfossil malacofauna of entire groups of profiles, typically formed of deposits of similar origin (e.g., Alexandrowicz, 1997, 2004, 2013a). Against this background, the malacofauna of tufa cones is a subject that has not been thoroughly explored yet. The fauna of these sites is mentioned in several general studies only (Alexandrowicz et al., 1985; Alexandrowicz, 1988, 2004; Alexandrowicz and Alexandrowicz, 1995), hence the need to describe the sites in more detail, especially as they represent a unique and exceptional type of deposits containing characteristic molluscan assemblages with a specific composition, structure and sequence. The main aim of this paper is therefore to describe subfossil molluscan assemblages occurring in tufa cones, as a basis for stratigraphic interpretations and palaeogeographical reconstructions. The results of such analysis concerning very young deposits may, and should be used in the studies of older formations and, as such, can be considered uniformitarian. A separate issue raised in this paper is the use of malacological analysis in the reconstruction of short-term climatic changes. Such studies were conducted several times, both in the Pieniny Mountains (Alexandrowicz, 1990, 1993, 2010, 2013a) and neighbouring areas, although they concerned mostly fluvial deposits (e.g., Alexandrowicz, 1997, 2009, 2010, 2013b). Considering the specificity of tufa sedimentation in the cones, these deposits are suitable for such analyses.

\section{GEOLOGICAL SETTING}

The Pieniny Mountains are part of the Pieniny Klippen Belt which extends in an arc reaching $600 \mathrm{~km}$ in length and ranging from several hundred metres to $20 \mathrm{~km}$ in width from near Vienna in Austria to the Carpathian Maramures Mountains in Romania. It does not form a solid mountain massif, but rather a series of isolated rocks that have emerged by denudation processes from beneath Paleogene, Neogene and Quaternary deposits. In Poland and Slovakia, it occurs as a small and low, compact mountain range. The Pieniny Mountains have a highly complex geological structure, with the most prominent role of Mesozoic limestone. A characteristic feature of the Pieniny relief is the Dunajec River Gorge, reaching $300 \mathrm{~m}$ depth in some places. Numerous side valleys enter the Dunajec River valley, many of which have the form of vertical-sided canyons. Such areas create favourable conditions for the accumulation of subhygropetric calcareous tufas. These deposits were found in ten locations during the field study. They have been grouped into four sites: Zawiasy (Zw) - three profiles, Sobczański Gorge (Ws) - three profiles, Gorczyński Gorge $(\mathrm{Wg})$ - two profiles, and Limbargowy Stream (Li) - two profiles (Fig. 2).

A preliminary malacological analysis was conducted in the Zawiasy (Alexandrowicz, 2004) and Sobczański Gorge (Alexandrowicz et al.,1985; Alexandrowicz, 1988, 2004) sites. The material studied at that time included only single samples and should be considered primarily as exploratory research. Studies conducted after the publication of these preliminary results have made it possible to collect further malacological samples and obtain material for radiocarbon dating, leading in turn to the much more detailed results and conclusions presented below. The sites in the Gorczyński Gorge and Limbargowy Stream are new profiles that have never been described before.

Zawiasy site $(\mathrm{Zw})$ is located on the left bank of the Dunajec River, approx. $700 \mathrm{~m}$ south-west of the centre of Krościenko (GPS: $49^{\circ} 25^{\prime} 36^{\prime \prime} \mathrm{N} ; 2^{\circ} 26^{\prime} 25^{\prime \prime} \mathrm{E}$; Fig. 2). In small niches in the rock slope with $45-50^{\circ}$ inclination, three tufa cones (Zw-I-Zw-III) were found, represented by fine-grained, silty calcareous tufas containing an admixture of sharp-edged limestone clasts. The thickness of exposed tufas in Zw-I and Zw-III profiles is $0.5 \mathrm{~m}$, and in $\mathrm{Zw}$-II profile $-0.8 \mathrm{~m}$. A sample for radiocarbon dating was obtained from the bottom part of section Zw-I (sample C-1: $320 \pm 40{ }^{14} \mathrm{C}$ BP (MKL-1353); 1496-1646 cal AD; Fig. 3). 


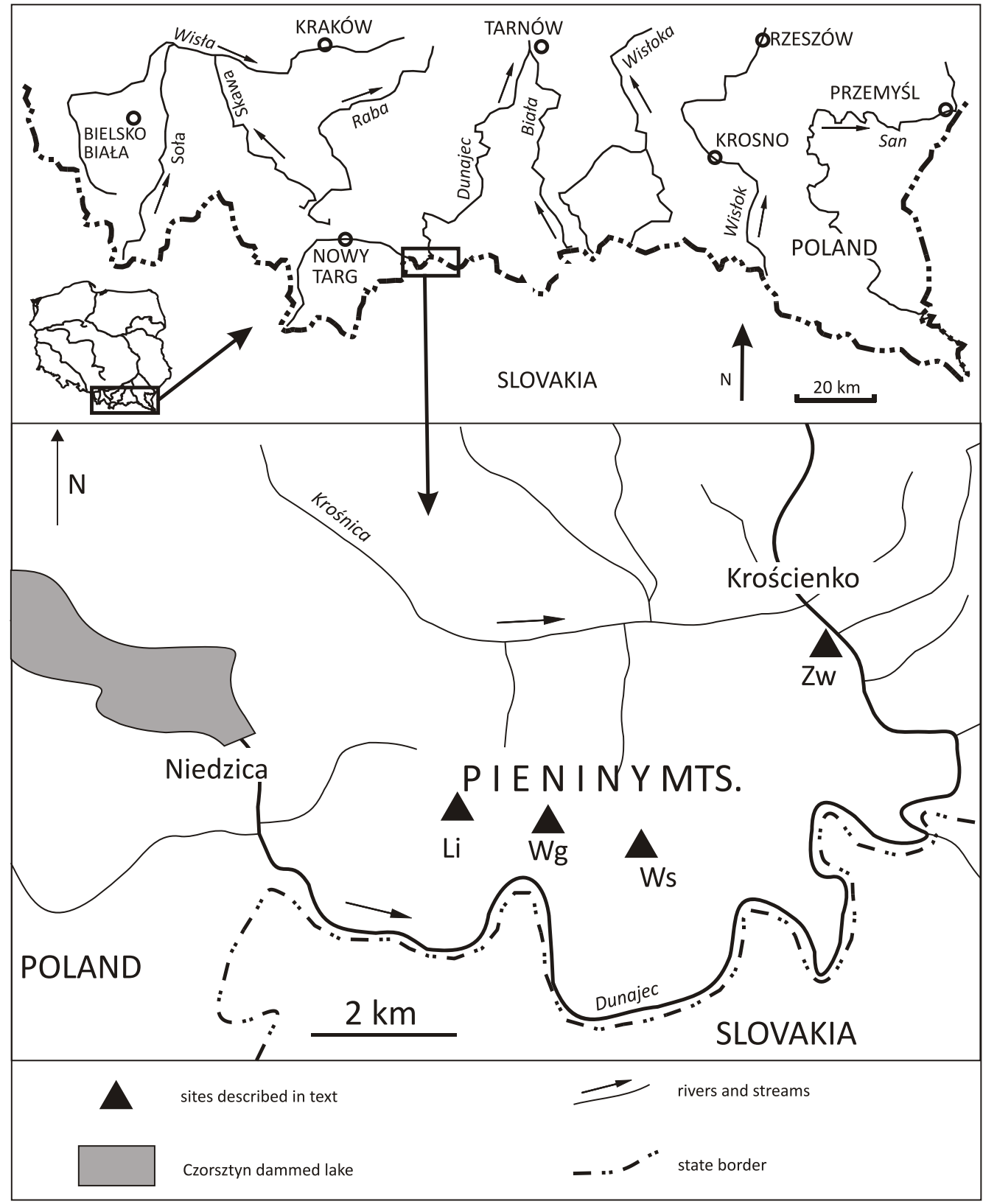

Fig. 2. Location of profiles of subhygropetric tufas cones in Pieniny Mts.

Li - Limbargowy Stream, Wg - Gorczyński Gorge, Ws - Sobczański Gorge, Zw - Zawiasy

Tufa cone profiles have also been found in the Sobczański Gorge (Ws) at the foot of vertical rock walls in the central part of the ravine (GPS: $49^{\circ} 24^{\prime} 41 " \mathrm{~N} ; 2^{\circ} 24^{\prime} 24^{\prime \prime} \mathrm{E}$ ). This ravine borders the highest massif of the Pieniny Mountains, the Trzy Korony Mountain (982 m a.s.I.). The largest profile (Ws-I) is approx. $1 \mathrm{~m}$ high, and the other two are $0.75 \mathrm{~m}$ (Ws-II) and $0.40 \mathrm{~m}$ (Ws-III) high. The age of two samples collected from profile Ws-I was established by radiocarbon dating. The first sample was taken from the lowermost part of the section (sample C-3: $620 \pm 80$ ${ }^{14} \mathrm{C}$ BP (MKL-1352); 1253-1431 cal AD). The second sample was taken from the top interval of the profile (sample $\mathrm{C}-2$ : $60 \pm 30{ }^{14} \mathrm{C}$ BP (MKL-1350); 1697-1916 cal AD; Fig. 3).

The next two tufa cone profiles have been found in the rocky part of the Gorczyński Gorge $(\mathrm{Wg})$ located north of Sromowce Niżne (GPS: $49^{\circ} 24^{\prime} 32 " \mathrm{~N} ; 2^{\circ} 23^{\prime} 19 " \mathrm{E} ;$; Fig. 2). Two small cones of white and yellowish silty calcareous tufas were formed adjacent to the vertical walls of the western flank of the ravine, reaching $0.50 \mathrm{~m}(\mathrm{Wg}-\mathrm{I})$ and $0.40 \mathrm{~m}(\mathrm{Wg}-\mathrm{II})$ in height. The age of the middle part of section Wg-I was determined by radiocarbon dating to be $140 \pm 70{ }^{14} \mathrm{C}$ BP (MKL-1351); 1650-1937 cal AD (Fig. 4).

The last site is situated in the rocky section of the Limbargowy Stream valley (Li) within the massif of Rabsztyn, north of Sromowce Wyżne (GPS: 49²4'59.3”N; 20²1'51.5”E; Fig. 2). Yellowish calcareous tufas with numerous limestone fragments fill a niche carved out of a rock slope inclined at $30^{\circ}(\mathrm{Li}-\mathrm{I})$ and at the foot of a vertical and partly overhanging rock wall in the narrowest part of the valley (Li-II). The cones are $0.9 \mathrm{~m} \mathrm{(Li-I)} \mathrm{and}$ $0.4 \mathrm{~m}$ (Li-II) high.

All profiles show a distinctly larger proportion of sharpedged limestone clasts in the uppermost sections. 

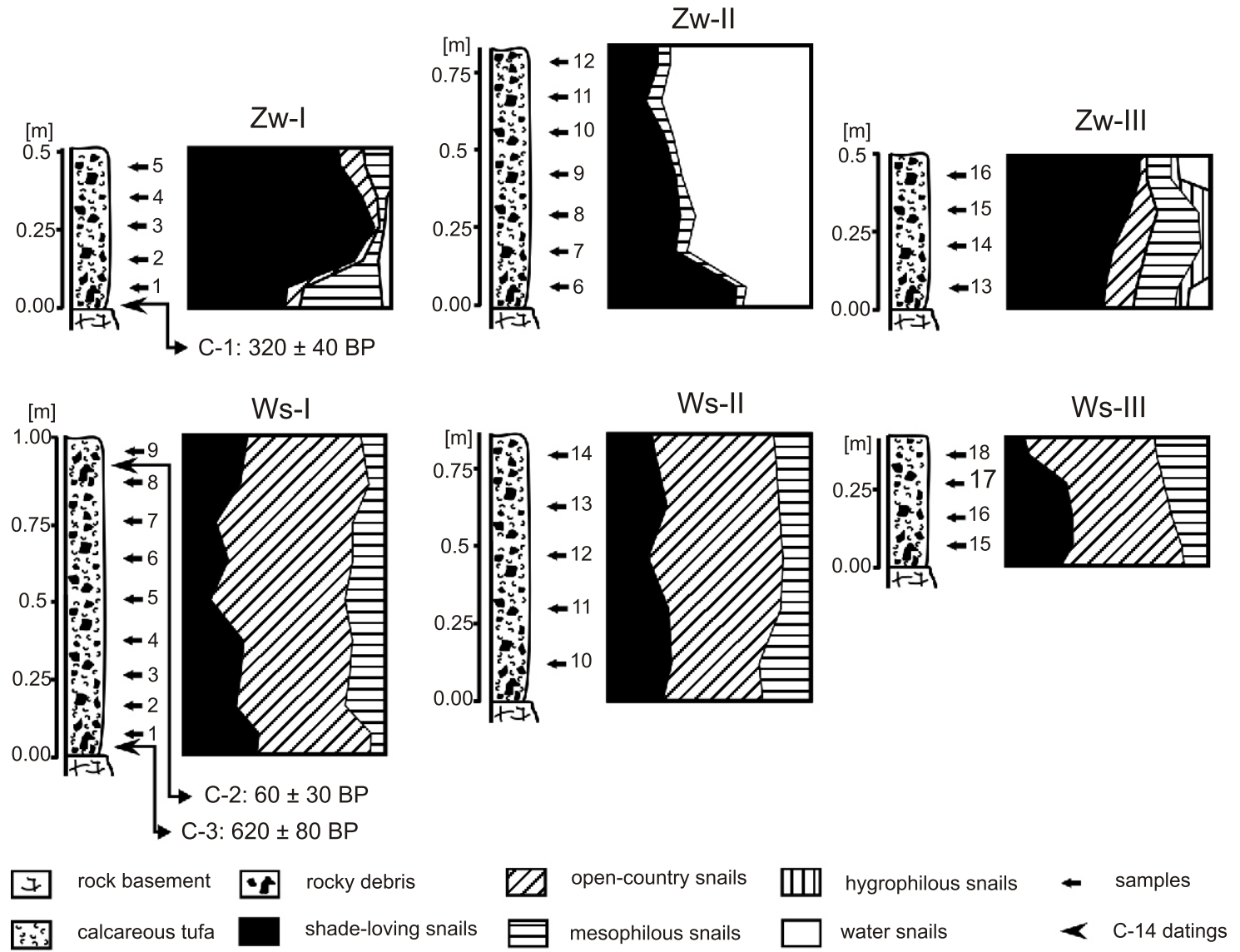

Fig. 3. Lithology and malacofauna of profiles in Sobczański Gorge (Ws) and Zawiasy (Zw)

Wg-I

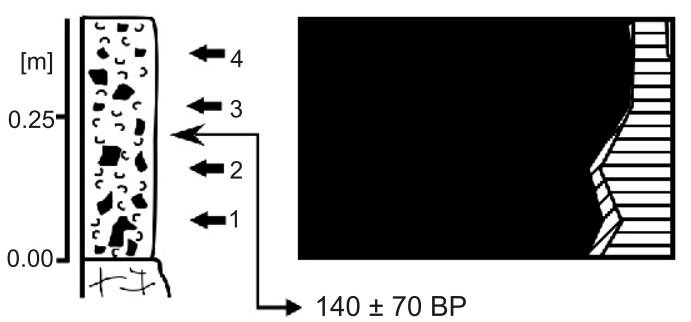

$\mathrm{Li}-\mathrm{I}$

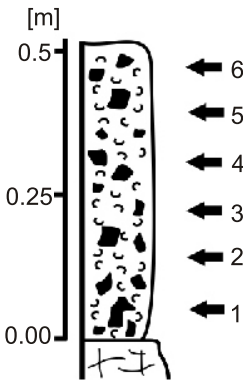

$[\mathrm{m}]$

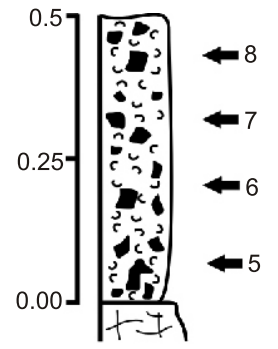

$\mathrm{Wg}-\mathrm{II}$

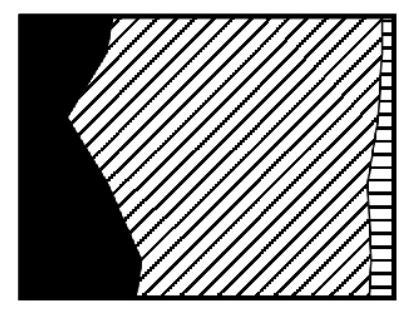

$\mathrm{Li}-\mathrm{II}$

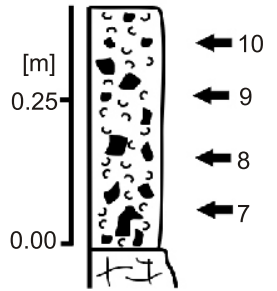

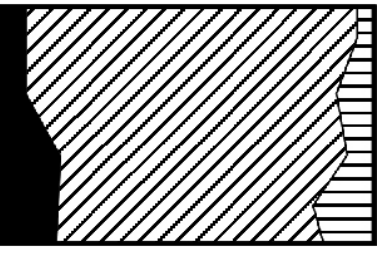

Fig. 4. Lithology and malacofauna of profiles in Gorczyński Gorge (Wg) and Limbargowy Stream (Li) 
Composition of malacofauna from tufas cones in Pieniny Mts.

\begin{tabular}{|c|c|c|c|c|c|c|c|c|c|c|c|}
\hline \multirow{2}{*}{$\mathrm{E}$} & \multirow{2}{*}{ Taxon } & \multicolumn{3}{|c|}{ Zw } & \multicolumn{3}{|c|}{ Ws } & \multicolumn{2}{|c|}{$\mathrm{Wg}$} & \multicolumn{2}{|c|}{$\mathrm{Li}$} \\
\hline & & $\mathrm{I}$ & II & III & 1 & II & III & 1 & II & 1 & II \\
\hline $\mathrm{F}$ & Acicula parcelineata (Cless.) & & $\mathrm{s}$ & & $S$ & & & $\mathrm{~S}$ & & $S$ & \\
\hline $\mathrm{F}$ & Platyla polita (Hartm.) & $\mathrm{R}$ & $\mathrm{R}$ & $\mathrm{R}$ & $\mathrm{R}$ & $S$ & $\mathrm{R}$ & $R$ & $S$ & $\mathrm{~N}$ & $S$ \\
\hline $\mathrm{F}$ & Vertigo pusilla Müll. & $\mathrm{R}$ & & $\mathrm{S}$ & $S$ & $\mathrm{R}$ & $\mathrm{R}$ & $\mathrm{S}$ & & $\mathrm{R}$ & \\
\hline $\mathrm{F}$ & Sphyradium doliolum (Brug.) & & $S$ & $\mathrm{~S}$ & & & & & $\mathrm{R}$ & & \\
\hline $\mathrm{F}$ & Argna bielzi (Rossm.) & $\mathrm{S}$ & $R$ & $\mathrm{~S}$ & $S$ & & & $\mathrm{~S}$ & & $\mathrm{R}$ & \\
\hline $\mathrm{F}$ & Acanthinula aculeata (Müll.) & $S$ & $\mathrm{R}$ & $\mathrm{S}$ & & $S$ & $S$ & $\mathrm{R}$ & & $\mathrm{R}$ & \\
\hline $\mathrm{F}$ & Ena montana (Drap.) & $\mathrm{R}$ & $\mathrm{R}$ & $\mathrm{R}$ & $S$ & $S$ & $S$ & $\mathrm{R}$ & & & \\
\hline $\mathrm{F}$ & Discus perspectivus (Mühlf.) & & $\mathrm{R}$ & $\mathrm{S}$ & & & & & & $\mathrm{N}$ & \\
\hline $\mathrm{F}$ & Discus rotundatus (Müll.) & $\mathrm{R}$ & $\mathrm{S}$ & & & & & $S$ & & $\mathrm{R}$ & \\
\hline $\mathrm{F}$ & Discus ruderatus (Hart.) & $\mathrm{S}$ & $\mathrm{S}$ & $\mathrm{R}$ & & $S$ & $S$ & & & S & \\
\hline $\mathrm{F}$ & Eucobresia nivalis (Dum et Mort.) & $\mathrm{S}$ & S & $\mathrm{R}$ & $\mathrm{C}$ & $\mathrm{N}$ & $\mathrm{N}$ & $\mathrm{N}$ & $\mathrm{R}$ & $\mathrm{C}$ & $\mathrm{R}$ \\
\hline $\mathrm{F}$ & Semilimax semilimax (Fér.) & $\mathrm{S}$ & $S$ & $\mathrm{~S}$ & & & & $\mathrm{~S}$ & & $\mathrm{~S}$ & \\
\hline $\mathrm{F}$ & Semilimax kotulae (West.) & $S$ & & & & & & & & & \\
\hline $\mathrm{F}$ & Vitrea diaphana (Stud.) & $\mathrm{R}$ & C & $\mathrm{R}$ & $S$ & $S$ & $\mathrm{R}$ & $\mathrm{N}$ & $S$ & $\mathrm{C}$ & \\
\hline $\mathrm{F}$ & Vitrea transsylvanica (Cless.) & $\mathrm{R}$ & $\mathrm{S}$ & $\mathrm{R}$ & $S$ & & & $\mathrm{~S}$ & & $\mathrm{R}$ & \\
\hline $\mathrm{F}$ & Vitrea subrimata (Reinh.) & $\mathrm{R}$ & $\mathrm{R}$ & $\mathrm{S}$ & & & & $\mathrm{R}$ & & $\mathrm{N}$ & \\
\hline $\mathrm{F}$ & Vitrea crystallina (Müll.) & $\mathrm{N}$ & $\mathrm{C}$ & $\mathrm{C}$ & $S$ & $\mathrm{R}$ & $S$ & $\mathrm{C}$ & $\mathrm{R}$ & $\mathrm{C}$ & $\mathrm{S}$ \\
\hline $\mathrm{F}$ & Aegopinella minor (Stab.) & $\mathrm{S}$ & $\mathrm{R}$ & $\mathrm{R}$ & & & & $\mathrm{S}$ & $\mathrm{S}$ & $\mathrm{R}$ & \\
\hline $\mathrm{F}$ & Aegopinella nitidula (Drap.) & & $\mathrm{R}$ & $S$ & & & & & & $S$ & \\
\hline $\mathrm{F}$ & Aegopinella pura (Ald.) & $\mathrm{R}$ & $\mathrm{C}$ & $\mathrm{C}$ & $S$ & $\mathrm{R}$ & $\mathrm{R}$ & $\mathrm{R}$ & & $\mathrm{N}$ & $\mathrm{S}$ \\
\hline $\mathrm{F}$ & Oxychilus orientalis (Cless.) & $S$ & $\mathrm{R}$ & & & & & & & & \\
\hline $\mathrm{F}$ & Oxychilus depressus (Sterki) & $\mathrm{R}$ & $\mathrm{R}$ & $S$ & $S$ & $\mathrm{R}$ & $\mathrm{R}$ & $S$ & $S$ & $\mathrm{R}$ & \\
\hline $\mathrm{F}$ & Daudebardia rufa (Drap.) & $\mathrm{S}$ & & $\mathrm{s}$ & & & & & & $\mathrm{s}$ & \\
\hline $\mathrm{F}$ & Daudebardia brevipes (Drap.) & & $\mathrm{S}$ & & & & & $\mathrm{S}$ & & $\mathrm{S}$ & \\
\hline $\mathrm{F}$ & Cochlodina laminata (Mont.) & $\mathrm{S}$ & & $\mathrm{S}$ & & $S$ & $\mathrm{~s}$ & $\mathrm{~S}$ & & $\mathrm{~N}$ & \\
\hline $\mathrm{F}$ & Cochlodina orthostoma (Menke) & $\mathrm{R}$ & & $\mathrm{S}$ & & $\mathrm{S}$ & $S$ & $\mathrm{~S}$ & $\mathrm{R}$ & $\mathrm{N}$ & $\mathrm{S}$ \\
\hline $\mathrm{F}$ & Ruthenica filograna (Rossm.) & $\mathrm{R}$ & $\mathrm{R}$ & $\mathrm{R}$ & $S$ & & & $\mathrm{~N}$ & & $\mathrm{~N}$ & $\mathrm{~S}$ \\
\hline $\mathrm{F}$ & Macrogastra plicatula (Drap.) & & $S$ & $S$ & & & & $\mathrm{~S}$ & & $\mathrm{R}$ & \\
\hline $\mathrm{F}$ & Macrogastra latestriata (Schm.) & $\mathrm{S}$ & $\mathrm{S}$ & $\mathrm{S}$ & & $S$ & $S$ & $\mathrm{R}$ & & $\mathrm{R}$ & \\
\hline $\mathrm{F}$ & Macrogastra tumida (Rossm.) & & & $S$ & & & & & & & \\
\hline $\mathrm{F}$ & Clausilia cruciata (Stud.) & $\mathrm{R}$ & $S$ & $\mathrm{~S}$ & & $\mathrm{~N}$ & $\mathrm{R}$ & $\mathrm{N}$ & $S$ & C & $\mathrm{R}$ \\
\hline $\mathrm{F}$ & Alinda biplicata (Mont.) & & $\mathrm{S}$ & $\mathrm{S}$ & $S$ & & & $\mathrm{~S}$ & & $\mathrm{~S}$ & \\
\hline $\mathrm{F}$ & Pseudalinda stabilis (L.Pfe.) & & $\mathrm{N}$ & $\mathrm{S}$ & & & $\mathrm{S}$ & $\mathrm{N}$ & $\mathrm{R}$ & $\mathrm{N}$ & $S$ \\
\hline $\mathrm{F}$ & Vestia gulo (Bielz) & & $S$ & & $S$ & & & & & & \\
\hline $\mathrm{F}$ & Vestia turgida (Rossm.) & & $\mathrm{S}$ & $S$ & & & $S$ & & & & \\
\hline $\mathrm{F}$ & Fruticola fruticum (Müll.) & $\mathrm{R}$ & $S$ & $S$ & & & & $\mathrm{~N}$ & $S$ & $\mathrm{~N}$ & \\
\hline $\mathrm{F}$ & Monachoides incarnatus (Müll.) & $\mathrm{N}$ & S & & $\mathrm{R}$ & & & $\mathrm{R}$ & & $\mathrm{C}$ & \\
\hline $\mathrm{F}$ & Monachoides vicinus (Rossm.) & $\mathrm{C}$ & $\mathrm{S}$ & $S$ & $S$ & & & $\mathrm{~N}$ & $S$ & $\mathrm{C}$ & $\mathrm{S}$ \\
\hline $\mathrm{F}$ & Perforatella bidentata (Gmel.) & $\mathrm{R}$ & & $\mathrm{S}$ & & & & & & & \\
\hline $\mathrm{F}$ & Urticicola umbrosa (C.Pfe.) & $\mathrm{N}$ & & & & & & & & & \\
\hline $\mathrm{F}$ & Faustina faustina(Rossm.) & $\mathrm{C}$ & $\mathrm{S}$ & $\mathrm{s}$ & $\mathrm{N}$ & $\mathrm{R}$ & $\mathrm{R}$ & $\mathrm{N}$ & $\mathrm{R}$ & $\mathrm{C}$ & $\mathrm{R}$ \\
\hline $\mathrm{F}$ & Petasina unidentata (Drap.) & $\mathrm{N}$ & & & $\mathrm{N}$ & $\mathrm{R}$ & $\mathrm{R}$ & $\mathrm{N}$ & $\mathrm{R}$ & $\mathrm{C}$ & $\mathrm{S}$ \\
\hline $\mathrm{F}$ & Isognomostoma isogn. (Schr.) & $\mathrm{C}$ & $\mathrm{R}$ & $\mathrm{R}$ & $S$ & $S$ & $S$ & $\mathrm{~N}$ & $S$ & $\mathrm{R}$ & $\mathrm{R}$ \\
\hline $\mathrm{F}$ & Arianta arbustorum (L.) & $\mathrm{N}$ & $\mathrm{R}$ & $S$ & $\mathrm{R}$ & $S$ & $S$ & $\mathrm{R}$ & $S$ & $\mathrm{~N}$ & $\mathrm{~S}$ \\
\hline $\mathrm{O}$ & Pyramidula pusilla (Vallot) & $S$ & & & A & $\mathrm{C}$ & $\mathrm{C}$ & $\mathrm{R}$ & $\mathrm{C}$ & $\mathrm{S}$ & $\mathrm{C}$ \\
\hline $\mathrm{O}$ & Truncatellina cylindrica (Fér.) & $S$ & & $\mathrm{~S}$ & $\mathrm{C}$ & $\mathrm{C}$ & $\mathrm{C}$ & & $\mathrm{C}$ & & $\mathrm{C}$ \\
\hline $\mathrm{O}$ & Pupilla sterri (Voith) & & & & C & $\mathrm{C}$ & $\mathrm{N}$ & & $\mathrm{N}$ & & $\mathrm{N}$ \\
\hline $\mathrm{O}$ & Pupilla muscorum (L.) & $S$ & & $S$ & $\mathrm{R}$ & $\mathrm{R}$ & $\mathrm{R}$ & & $\mathrm{S}$ & $S$ & $\mathrm{~N}$ \\
\hline $\mathrm{O}$ & Vertigo pygmaea (Drap.) & & & & & & & & $\mathrm{S}$ & $\mathrm{s}$ & $\mathrm{N}$ \\
\hline $\mathrm{O}$ & Chondrina clienta (West.) & $\mathrm{R}$ & & & C & $\mathrm{C}$ & $\mathrm{C}$ & $\mathrm{R}$ & C & $S$ & C \\
\hline $\mathrm{O}$ & Vallonia costata (Müll.) & $\mathrm{R}$ & $S$ & $\mathrm{C}$ & $\mathrm{R}$ & $S$ & & & $S$ & & $\mathrm{R}$ \\
\hline $\mathrm{O}$ & Vallonia pulchella (Müll.) & $\mathrm{R}$ & & $\mathrm{S}$ & & $S$ & & $S$ & $S$ & $S$ & $\mathrm{R}$ \\
\hline $\mathrm{O}$ & Euomphalia strigela (Drap.) & & & & $\mathrm{s}$ & $S$ & & & & & \\
\hline
\end{tabular}


Tab. 1 cont.

\begin{tabular}{|c|c|c|c|c|c|c|c|c|c|c|c|}
\hline M & Carychium tridentatum (Risso) & $\mathrm{R}$ & $\mathrm{N}$ & C & $\mathrm{s}$ & $\mathrm{s}$ & & & & $\mathrm{N}$ & \\
\hline $\mathrm{M}$ & Cochlicopa lubnica (Müll.) & $S$ & $S$ & $\mathrm{R}$ & & $S$ & & $S$ & $S$ & $\mathrm{R}$ & $\mathrm{S}$ \\
\hline M & Succinella oblonga Drap. & & $S$ & $\mathrm{R}$ & & & & & & & \\
\hline M & Columella edentula (Drap.) & & $S$ & $S$ & & & & $\mathrm{R}$ & & $\mathrm{R}$ & \\
\hline M & Vertigo alpestris Ald. & $\mathrm{R}$ & $S$ & & $\mathrm{~N}$ & $\mathrm{~N}$ & $\mathrm{~N}$ & $\mathrm{R}$ & & $\mathrm{N}$ & $\mathrm{S}$ \\
\hline M & Vertigo substriata (Jeffr.) & $S$ & $\mathrm{R}$ & $S$ & & & & $\mathrm{~N}$ & & $\mathrm{~N}$ & $\mathrm{~S}$ \\
\hline$M$ & Punctum pygmaeum (Drap.) & $\mathrm{s}$ & $S$ & $S$ & $\mathrm{R}$ & $\mathrm{R}$ & $\mathrm{R}$ & $\mathrm{s}$ & $S$ & $\mathrm{R}$ & $\mathrm{S}$ \\
\hline M & Vitrea contracta (West.) & $\mathrm{R}$ & $S$ & $S$ & & & & & & & \\
\hline$M$ & Vitrina pellucida (Müll.) & $\mathrm{s}$ & $S$ & $S$ & & & & $S$ & $S$ & $\mathrm{R}$ & \\
\hline$M$ & Perpolita hammonis (Ström) & $\mathrm{s}$ & & $S$ & & & & $\mathrm{~S}$ & & $S$ & \\
\hline M & Perpilita petronella (L.Pfe.) & $S$ & & $S$ & & & & & & & \\
\hline M & Limacidae & $S$ & & $S$ & & $S$ & $\mathrm{~S}$ & $S$ & $S$ & $\mathrm{R}$ & $\mathrm{R}$ \\
\hline $\mathrm{M}$ & Euconulus fulvus (Müll.) & $S$ & $S$ & $S$ & $\mathrm{R}$ & $S$ & $\mathrm{~S}$ & $S$ & $S$ & $\mathrm{R}$ & $\mathrm{S}$ \\
\hline M & Clausilia dubia Drap. & $\mathrm{R}$ & & $S$ & C & $\mathrm{N}$ & $\mathrm{C}$ & $\mathrm{N}$ & $\mathrm{R}$ & $\mathrm{N}$ & $\mathrm{N}$ \\
\hline M & Trichulus villosulus (Rossm.) & & & $S$ & & & & & & & \\
\hline $\mathrm{H}$ & Carychium minimum Müll. & $S$ & $S$ & $\mathrm{R}$ & & & & & & $\mathrm{S}$ & \\
\hline $\mathrm{H}$ & Succinea putris (L.) & & & $S$ & & & & & & & \\
\hline W & Bythinella austriaca (Frfld.) & & $\mathrm{V}$ & $\mathrm{R}$ & & & & $S$ & & $\mathrm{M}$ & \\
\hline W & Galba truncatula (Müll.) & $\mathrm{R}$ & & $S$ & & & & & & & \\
\hline
\end{tabular}

E - ecological groups of molluscs (after Ložek, 1964; Alexandrowicz, 1987; Alexandrowicz and Alexandrowicz, 2011): F shade-loving species, $\mathrm{H}$ - hygrophilous species, $\mathrm{M}$ - mesophilous species, $\mathrm{O}$ - open-country species (meadow species), $\mathrm{W}-$ water species; frequency of species: $\mathrm{A}$ - abundant, $\mathrm{C}$ - common, $\mathrm{N}$ - few, $\mathrm{R}$ - rare, $\mathrm{S}$ - single, $\mathrm{V}$ - very abundant; localities: $\mathrm{Li}$ - Limbargowy Stream, Wg - Gorczyński Gorge, Ws - Sobczański Gorge, Zw - Zawiasy

\section{MATERIAL AND METHOD}

A total of 52 samples were collected from the above-presented sites for malacological investigation (Table 1). Each weighed $1.5-2.0 \mathrm{~kg}$ and represented a $10-20 \mathrm{~cm}$ interval, depending on the lithological features of sediments. The laboratory processing of the materials included maceration and flushing of rocks, followed by the collection of all complete molluscan shells and their identifiable fragments. The identification of shell material was done vis-á-vis classification keys and comparative collections. The numbers of species and specimens were determined for each sample. The pieces of shells were calculated into whole specimens according to the formula proposed by Ložek (1964) and Alexandrowicz $(1987 ; 1-3 f=1 \mathrm{~s}, 4-7 f=2 \mathrm{~s}$, $8-20 f=4 s, 20-50 f=6 s, 50-75 f=10 s, 75-100 f=12 \mathrm{~s}$, $>100 f=14 \mathrm{~s}: \mathrm{f}-$ fragments of shells, $s-$ specimens). The number of species per sample varied from 12 to 54 , whereas the number of specimens ranged from 116 to 843 , respectively. The entire material studied comprised 14,660 specimens of 72 taxa (69 terrestrial and 2 aquatic snail taxa). Additionally, the calcareous plates of slugs were included under the collective name Limacidae (Table 1). The molluscan fauna represents as much as $79 \%$ of all terrestrial species (excluding slugs) presently occurring in the Pieniny Mts. (Urbański, 1939; Riedel, 1982, 1988). All species identified in the presented profiles can currently be found living in the Pieniny Mountains.

The malacological analysis was performed using the methods described by Ložek (1964), Alexandrowicz (1987) and Alexandrowicz and Alexandrowicz (2011). The species were classified into ecological groups: $\mathrm{F}$ - shade-loving species, $\mathrm{O}$ open-country species (meadow species), M - mesophilous species, $\mathrm{H}$ - hygrophilous species, and $\mathrm{W}-$ water species. The results of ecological analyses performed in numerous Holocene deposit sites show explicitly that ecological preferences of individual species did not undergo any significant change throughout this period. The percentage shares of the ecological groups, as well as of the selected most typical species, enabled us to construct malacological diagrams. The latter provided a basis for palaeoenvironmental interpretations. The ratios between ecological groups were used as a basis to construct a ternary diagram and therefore distinguish the major types of fauna. The taxonomic analysis made it possible to determine similarities between particular samples and to mark the groups of samples with molluscan assemblages of similar composition and structure. A dendrogram was developed with the use of the method described by Morisita (1959). Statistical calculations were completed using the PAST statistical software package (Hammer et al., 2001). The age of the described deposits was determined on the basis of malacological data and by performing four radiocarbon dating. The objects of the analysis were the shells of large snails from the Helicidae family. The radiocarbon analysis was carried out at the Radiocarbon Laboratory in Skała (laboratory reference number: MKL). The results were calibrated using OxCal software (Bronk Ramsey, 2003).

\section{RESULTS}

The profiles contain abundant and diverse malacofauna representing all ecological groups, although their significance is varied. Shade-loving species (ecological group F) occur in the greatest numbers (a total of 44 taxa). This group includes both snails inhabiting forest habitats, mainly deciduous forests (Platyla polita, Aegopinella pura, Ruthenica filograna, Clausilia cruciata, Isognomostoma isognomostomos), and forms typical of shaded rocks (Eucobresia nivalis, Oxychilus depressus, Cochlodina orthostoma, Faustina faustina), as well as shrubland species (Vitrea crystallina, Arianta arbustorum), whereas shade-loving taxa preferring habitats with higher humidity are relatively scarce (Monachoides vicinus; Table 1). A majority of the taxa identified are common forms, spread in large areas of Poland. Rare species of narrow geographical ranges, Carpathian endemics 
(Acicula parcelineata, Pseudalinda stabilis, Vestia gulo, Vestia turgida), have also been found. Shade-loving species occur in particularly large numbers in the deposits from profiles $Z w-l$, $\mathrm{ZW}-\mathrm{III}$ and $\mathrm{Wg}-\mathrm{I}$, where they represent the dominant component of the assemblage. Their proportion can reach up to $90 \%$ (Figs. 3 and 4). These sites contain mostly tufas accumulating inside niches and hollows formed in slanting rock walls (type C; Fig. 1). The second ecological group of considerable importance is represented by open-country species (ecological group $\mathrm{O}, 9$ taxa). The dominant role in this group is played by petrophilous snails living on bare limestone rocks (Pyramidula pusilla, Truncatellina cylindrica, Chondrina clienta). Forms typical of grass biotopes are of much less significance (Pupilla muscorum, Vallonia pulchella, Vallonia costata). Open-country taxa (largely petrophilous) constitute the dominant group in the deposits accumulating at the foot of vertical rock sides or in the cones formed underneath overhangs (types A and B; Fig. 1). The proportion of shade-loving species in some of the profiles can reach even $90 \%$. Such malacocoenoses have been identified in sites Ws-I, Ws-II, Ws-III, Wg-II and Li-II (Figs. 3 and 4). Mesophilous species (ecological group M, 15 taxa) occur in all samples (Table 1). However, they are always a supplementary element, and never the dominant component of the assemblage (Figs. 3 and 4). These forms may occur in biotopes of different shading and humidity levels. Nonetheless, these species often prefer a rocky substrate. They can be found in all types of the deposits. Hygrophilous snails (ecological group $\mathrm{H}$ ) occur very rarely and constitute merely an accessory component of assemblages ( $\mathrm{Ta}$ ble 1), while most samples lack them completely (Figs. 3 and 4). Water species (ecological group W) are represented by two taxa only. However, one of them, Bythinella austriaca, constitutes an essential, locally even dominant component of the malacocoenoses (Table 1). This form is typical of spring zones and occurs in great abundance in these biotopes. The species is found in very large numbers in near-spring calcareous tufas which are currently in the process of precipitation, described in the Pieniny Mountains and Podhale region (Alexandrowicz, 1997, 2004, 2010, 2013a), as well as the Flysch Carpathians (Alexandrowicz, 2004, 2009). The high frequency of Bythinella austriaca is typical of tufas that have accumulated in niches and hollows formed in slanting rock walls in the direct vicinity of springs (type C; Fig. 1) and it was observed in sites Zw-II and Li-I (Figs. 3 and 4).

The presented calcareous tufa profiles forming cones adjacent to rock walls are marked by fairly similar lithological features. The variability of the composition and structure of malacocoenoses in vertical profiles is also relatively low (Figs. 3 and 4). Furthermore, the tufas are a uniform group in terms of the sedimentation mechanism. It was therefore possible to determine the constancy and dominance of structures for the entire material collected, and consequently to indicate the most important and most numerous species.

\section{DISCUSSION}

The malacofauna of calcareous tufas accumulating beside rock walls contains species living exclusively in the direct vicinity of the sediments. The diversity of habitats is thus strongly reflected in the composition and structure of malacocoenoses. The differences in the composition and structure of malacocoenoses noted in the individual samples can be suitably illustrated in a ternary diagram and in a dendrogram (Figs. 5 and 6). The projection points are clearly clustered in three areas. Based on this, three main types of fauna from the tufa cones can be distinguished. The individual assemblages

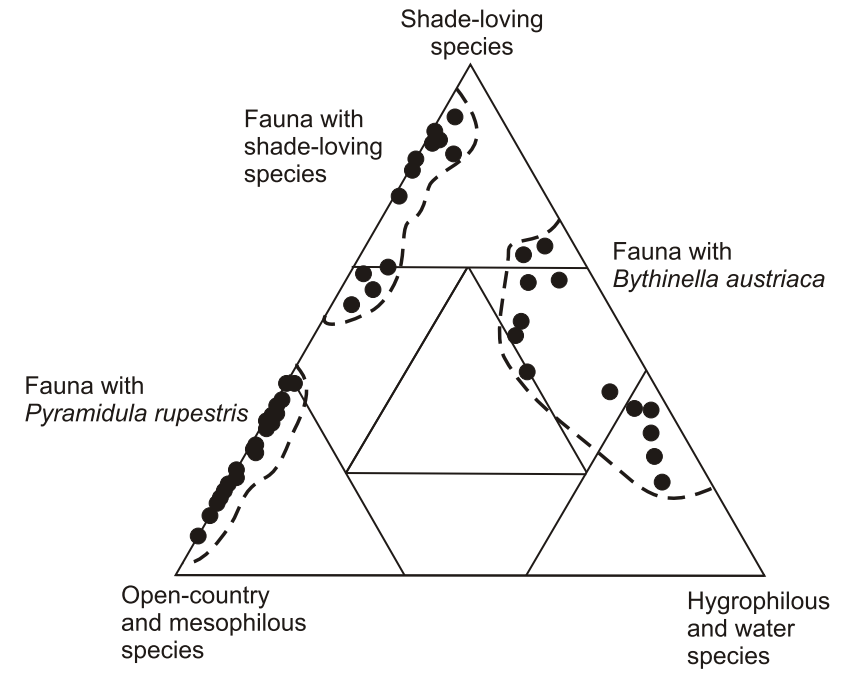

Fig. 5. Ecological differentiation of molluscan assemblages from tufas cones in Pieniny Mts.

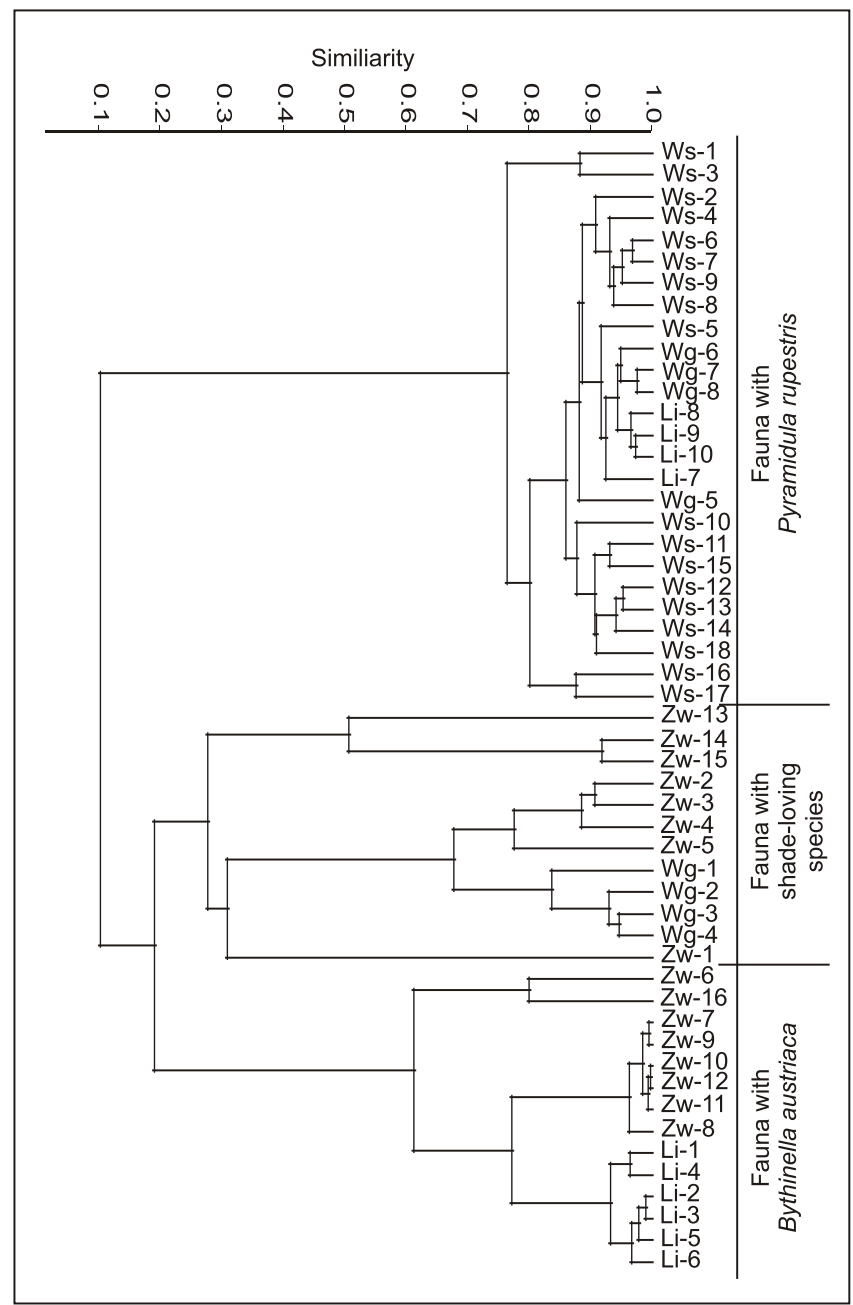

Fig. 6. Cluster analysis of malacofauna of profiles of subhygropetric tufas cones in Pieniny Mts. 
represent environmental conditions that prevailed during the deposition.

The Bythinella austriaca assemblage is marked by the predominant proportion of the nominal species that can be very numerous. This form is characteristic of sediments deposited in the immediate vicinity of springs. This is the main component of the malacocoenoses of Late Holocene calcareous tufas, and has been reported in numerous sites of such deposits in the Podhale Basin, Pieniny Mountains, and Flysch Carpathians (Alexandrowicz, 1997, 2004, 2009, 2010, 2013a). The supplementary components are mesophilous and shade-loving species, while forms typical of open spaces are usually rare. This malacocoenosis was identified in samples representing profiles Zw-II and Li-I (Figs. 5 and 6; Table 1). It is mostly associated with tufas accumulating nearby springs and filling hollows in rock slopes inclined at a relatively small angle (type C; Fig. 1).

The Pyramidula pusilla assemblage contains a major proportion of forms living in open space habitats. Particularly significant components of this malacocoenosis are petrophilous and xerophilous snails occurring on limestone rocks: Pyramidula pusilla, Chondrina clienta. Locally, xerophilous forms typical of highly insulated and dry limestone outcrops (Pupilla sterri, Truncatellina cylindrica) also play a significant role. Other ecological groups are found in relatively small proportions, typically below $20 \%$. The Pyramidula pusilla assemblage was identified in the samples from outcrops in the Sobczański Gorge (Ws-I-Ws-III), as well as in profiles Li-II and Wg-II (Figs. 5 and 6 ; Table 1). This fauna is typical of calcareous tufas that accumulate at the foot of vertical, bare rock walls under overhangs (types A and B; Fig. 1). It also often occurs in talus cones forming at the mouth of wide rock crevices, and has been reported both in the Kraków-Częstochowa Upland (Alexandrowicz, S.W., 2000; Alexandrowicz, W.P., 2000) and the Podhale region (Alexandrowicz, 1997; Alexandrowicz and Stworzewicz, 2003; Alexandrowicz and Rudzka, 2006). Numerous sites with these deposits, some representing the entire Holocene, have been found in the Czech Republic and Slovakia (Ložek, 1959, 1961, 1962, 1963, 1964).

The shade-loving species assemblage is the most diverse malacocoenosis in terms of species composition. The dominant role is played by shade-loving snails, including forest forms (e.g., Platyla polita, Ruthenica filograna, Clausilia cruciata, Isognomostoma isognomostomos), species occurring on shaded limestone rocks (e.g., Eucobresia nivalis, Argna bielzi), and taxa typical of shrubland areas (e.g., Arianta arbustorum, Vitrea crystallina). The supplementation is comprised of mesophilous snails, and the remaining ecological groups are of lesser significance. The proportion of shade-loving forms is usually very high, reaching up to $90 \%$. An assemblage with such composition was found in samples from profiles $Z \mathrm{~W}-\mathrm{l}$, Zw-III and Wg-I (Figs. 5 and 6; Table 1), which represented Aand C-type tufas (Fig. 1) forming in highly shaded locations. Similar malacocoenoses were described in talus cone sites in the Tatra Mountains (Alexandrowicz, 1988, 2001; Gradziński et al., 2001; Smieja and Smieja-Król, 2007), Podhale region (Alexandrowicz, 1997; Alexandrowicz and Stworzewicz, 2003; Alexandrowicz and Rudzka, 2006), Kraków-Częstochowa Upland (Alexandrowicz, S.W., 1983, 2000; Alexandrowicz, W.P., 2000), and numerous Czech and Slovakian sites (Ložek, 1959, 1961, 1962, 1963, 1964).

Dendrogram analysis makes it possible to distinguish identical assemblages as those described above (Fig. 6), and to indicate the samples and profiles in which these assemblages occur. It should be stressed that samples collected from each profile show a high degree of resemblance. It suggests that fairly minor environmental changes took place during the depo- sition of the tufas. This is probably due to the short stratigraphic ranges of the profiles, which is supported by the dating results and the characteristics of the malacocoenoses.

Subhygropetric tufas identified in the Pieniny Mountains can be considered as deposits of largely uniform origin and age. Their location type and lithological similarity, as well as their fauna, with a composition resembling the assemblages currently occurring in the direct vicinity, support this fact. Climatic conditions prevailing in the deposition zones are very important for the formation of these deposits. All the sites are located at an elevation of 550-620 m a.s.I. The average annual temperature in this zone is $5.5-6^{\circ} \mathrm{C}$, total precipitation is $700-800 \mathrm{~mm}$ and the number of snow-cover days is 100-120 (Kostrakiewicz, 1982). However, it should be noted that the presented profiles are located in deeply carved ravines, which undoubtedly affects the climate conditions. It certainly favours the decrease in average annual temperatures and a longer snow-cover season, thus shortening the vegetation period. Observations continued over the last several years have shown a slow degradation of the cones. Hence, a conclusion can be drawn that denudation factors leading to the destruction of these forms outrun the deposition of tufas. A similar process has also been observed in the Tatra Mountains. A tufa cone described by Alexandrowicz (1988) in the Kraków Gorge was approx. 2 m high, and over a decade later (Alexandrowicz, 2004) only $1.5 \mathrm{~m}$ high. Studies conducted in the Slovakian Carpathians and the Czech Karst (Ložek, 1959, 1961, 1962, 1963, 1964), as well as the Polish Tatra Mountains (Alexandrowicz, 1988, 2001; Gradziński et al., 2001; Smieja and Smieja-Król, 2007), have shown that in many sites the cones are covered by limestone rubble, only occasionally cemented with tufa material. It implies a highly restricted calcium carbonate precipitation or even the halted deposition of the tufas. In the analysed profiles, it is manifested by a rapid increase in the number of rock clasts at the top of the sections.

The analysis of age and distribution of calcareous tufas in Europe demonstrates that the warm period during a climatic optimum (the Atlantic Phase) was particularly favourable for calcareous tufa deposition. The greatest number of sites representing these deposits correspond to this period (e.g., Jäger and Ložek, 1968; Alexandrowicz, 1983; Pazdur et al., 1988a, b; Pentecost, 1991, 1995; Alexandrowicz and Alexandrowicz, 1995; Füköh, 1995; Alexandrowicz, 1997, 2004, 2009, 2010; Meyrick and Preece, 2001; Gedda, 2001, 2006; Žák et al., 2002; Meyrick, 2002: Gradziński et al., 2013).

The age of the presented sites can be determined both directly, via the radiocarbon dating of four samples, and indirectly. The major indirect evidence includes: location type, the composition and structure of faunistic assemblages with their vertical profile variability, and the comparison to other sites of similar deposits with an established stratigraphic position. Elements such as: weak resistance of the cones to erosion agents, and the strong similarity of the molluscan assemblages of the tufas to malacocoenoses currently inhabiting the deposition zones, indicate that the discussed deposits were formed in the historic period (during the last few centuries).

Several climate fluctuations occurred at that time. A major warming took place in the 13-14th centuries, referred to as the Medieval Warm Period (Grove and Switsur, 1994; Huges and Diaz, 1994; Bradley, 2000; Briffa, 2000; Jones and Mann, 2004). This phase involved favourable conditions for the deposition of carbonate sediments (Alexandrowicz, 2004, 2009, 2010, 2013a). A cooling period which fell between the 14-19th centuries (the Little Ice Age; e.g., Bradley, 2000; Briffa, 2000; Mayewski et al., 2004; Matthews and Briffa, 2005) facilitated, in turn, the intense physical weathering processes, while reducing 
the rate of carbonate deposition in the Polish Carpathians (Alexandrowicz, 2004, 2009, 2010, 2013a).

At all the sites, the process of tufa sedimentation is currently still underway. It marks the uppermost stratigraphic boundaries of the profiles. The bottom boundaries are drawn on the basis of the radiocarbon results (profiles Ws-I and $\mathrm{Zw}-\mathrm{I}$ ) or malacofauna assemblages in the deposits. This evidence serves also as a basis for deriving a stratigraphic correlation between the profiles. The stratigraphic ranges of the profiles are presented in Figure 7. The oldest deposits are located in the bottom sections of profiles Ws-I and Zw-II. A radiocarbon analysis performed in profile Ws-I gave the result $620 \pm 80{ }^{14} \mathrm{C}$ BP (MKL-1352); 1253-1431 cal AD (sample C-3), which shows that the sedimentation of calcareous tufas began towards the close of the warm phase of the Medieval Warm Period (Fig. 7). This date coincides with a considerable proportion of shade-loving species found in both profiles, which suggests favourable conditions for the development of forests in this period. Malacocoenoses with a similar composition and of similar age have been reported in many sites in the Pieniny Mountains (Alexandrowicz, 1990, 2004, 2010, 2013a), Podhale region (Alexandrowicz, 1997, 2004, 2010, 2013b; Alexandrowicz and Rudzka, 2006), Tatra Mountains (Alexandrowicz, 1988, 2001), and Flysch Carpathians (Alexandrowicz, 2004, 2009). It is important to say that the large proportion of forest communities in this period is typical only of areas unaffected by human impact. The discussed profiles of tufa cones are located in areas hardly accessible and unattractive for settlement, cultivation and animal breeding. Therefore, human impact on the environment in their direct vicinity is negligible. The cooling brought on by the Little Ice Age is demonstrated by the reduced proportion of the shade-loving component in malacocoenoses. Its place was taken by more abundant mesophilous, and sometimes also hygrophilous forms. Petrophilous species play a dominant role in the profiles situated at the foot of rock walls. The aforementioned cooling and the resultant alteration of malacocoenoses are documented by radiocarbon dating performed in profiles Zw-I (320 \pm 40 14C BP (MKL-1353); 1496-1646 cal AD; sample C-1) and Wg-I (140 $\pm 70{ }^{14} \mathrm{C}$ BP (MKL-1351); 1650-1937 cal AD; sample $C-4)$. The significant reduction in the proportion of shade-loving species in the deposits representing the Little Ice Age cold phase has been very clearly identified in several profiles of tufa talus cones in the Tatra Mountains (Alexandrowicz, 1988, 2001). The tufa cones in the Pieniny area are located at a much lower elevation (550-620 m a.s.l.). Therefore, the deterioration in conditions for forest growth during climate fluctuations towards the cold is much less visible, and the structure of vertical profiles is much more stable. Similar regularities have also been reported in many calcareous tufa sites and fluvial deposits in the Pieniny Mts., Podhale region and Flysch Carpathians (Alexandrowicz, 1990, 1993, 1997, 2004, 2009, 2010, 2013b). Cooling of the climate also caused the tufa sedimentation to slow down, while simultaneously intensifying physical weathering processes. An indication of these processes is an increase in the proportion of scree material noted in the profiles. It is evident mainly in the profiles of deposits accumulating at the foot of rock walls. The deposits associated with the Little Ice Age period are represented in all profiles, forming their lower and middle sections (profiles $\mathrm{Zw}-\mathrm{I}, \mathrm{II}$, Ws-II, III, Wg, I, II, and Li-I, II) and their middle sections (profiles Zw-II and Ws-I; Fig. 7). The topmost intervals of all profiles correspond to the warming phase following the Little lce Age (radiocarbon date - top section of profile Ws-l: $60 \pm 30{ }^{14} \mathrm{C} \mathrm{BP}$ (MKL-1350); 1697-1916 cal AD; C-2; Fig. 7). This warming is reflected in the slowly increasing role played by shade-loving species in malacocoenoses. The disappearance of the forms

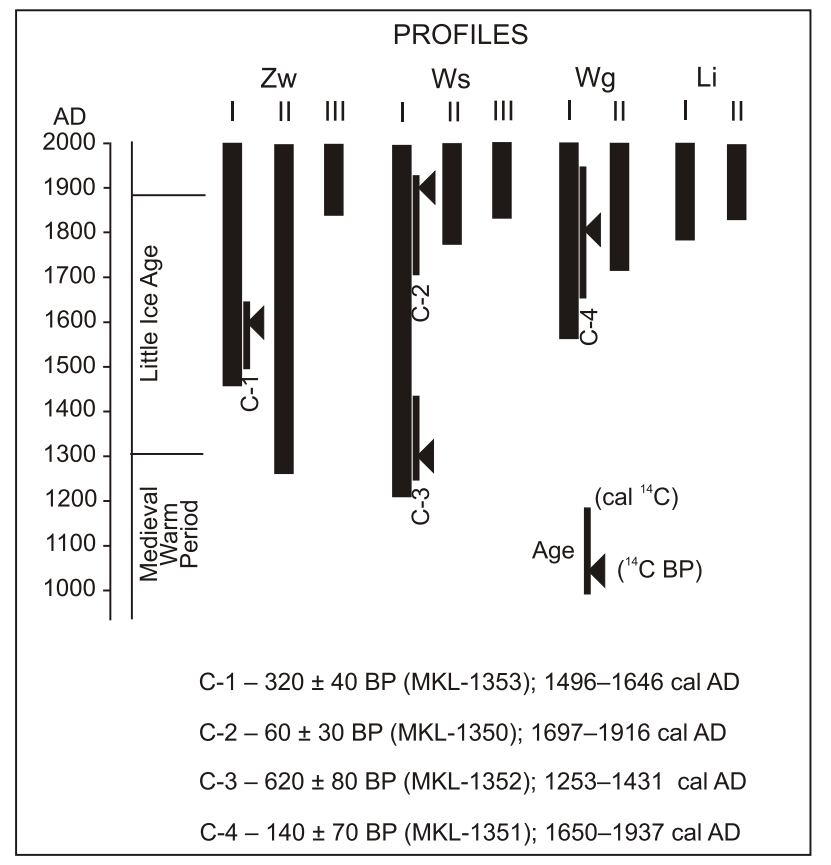

Fig. 7. Stratigraphy and correlation between profiles of subhygropetric tufas cones in Pieniny Mts.

typical of shaded environments noted in the uppermost sections of profiles Zw-I and Ws-III may indicate an initial phase of anthropogenic deforestation that occurred, however, much more faintly than in inner mountain basins (e.g., Podhale Basin; Alexandrowicz, 1997, 2010, 2013b), in the Carpathian foreland (Alexandrowicz and Alexandrowicz, 1995) and in the Mid-Polish Uplands (Alexandrowicz, 1983; Alexandrowicz et al., 1997).

\section{CONCLUSIONS}

Subhygropetric tufa sites found in the Pieniny Mountains contain abundant and diversified malacofauna. The molluscan assemblages distinguished during the malacological analysis clearly correspond to the main location types of the studied deposits. Malacocoenoses dominated by Bythinella austriaca are typical of tufas accumulated in the direct vicinity of springs, usually on rocky slopes inclined at a relatively small angle. They typically fill niches and hollows. A considerable admixture of shade-loving species is also usually observed in this case. Tufa cones adjacent to vertical rock sides or under overhangs contain faunas either dominated by petrophilous species or with a large proportion of shade-loving forms. The former is typical of open space sites, while the latter is characteristic of areas overgrown with dense shrubs or forest associations.

The tufas represent the historic period. The results of radiocarbon analyses and the characteristics of molluscan assemblages show that the sedimentation of tufas began towards the end of the warm phase of the Medieval Warm Period. The major phase of deposition falls within a cooler period corresponding to the Little Ice Age. This phase is documented both by radiocarbon dating results and the change observed in the structure of malacocoenoses, marked by the decrease in shade-loving species frequency. The top portions of the profiles correspond to a period of gradual climate warming that occurred in the 20th century. Calcium carbonate is currently being precipitated in all profiles. Alterations in the proportion of shade-loving species in malacocoenoses show a strong relationship to clima- 
tic changes. In cool phases, the frequency of shade-loving forms drops, while it rises in warmer phases. This phenomenon has been reported in numerous profiles in the Polish Carpathians (e.g., Alexandrowicz and Alexandrowicz, 1995; Alexandrowicz, 1997, 2004, 2009, 2010, 2013b), and particularly the Tatra Mountains (Alexandrowicz, 1988, 2001).

The examined tufa cones were formed during a period of intensified settlement in the Pieniny region and neighbouring areas (e.g., Kołodziejski et al., 1982; Obidowicz, 1990; Alexandrowicz, 1997, 2013b), and the ensuing anthropogenic pressure. The tufa cones, however, are located in areas unfavourable for exploitation by humans, and the profiles do not bear any sign of human activity. Therefore, the presented sites provide a record of natural changes in the environment, determined mostly by the climate. The comparison of the fauna found in the tufa cones located in the Pieniny and Tatra Mountains shows that their molluscan assemblages and sequences correspond to climatic changes. These structures can therefore be successfully used in palaeogeographical and stratigraphic reconstructions. They will also contribute to extending the interpretational capacities of the malacological method.

Acknowledgments. The author is greatly indebted to Dr. J. Hlavac and Dr. Y. Yanes for valuable critical remarks. This study was sponsored by the AGH University of Science and Technology through University grant No. 11.11.140.173.

\section{REFERENCES}

Alexandrowicz, S.W., 1983. Malacofauna of Holocene calcareous sediments of the Cracow Upland. Acta Geologica Polonica, 33 : 117-158.

Alexandrowicz, S.W., 1987. Malacological analysis in Quaternary research (in Polish with English summary). Geologia, 12 $3-240$.

Alexandrowicz, S.W., 1988. Cones of calcareous tufas in National Parks of Tatra Mts. and Pieniny Mts. (in Polish with English summary). Ochrona Przyrody, 46: 361-382.

Alexandrowicz, S.W., 1990. The malacofauna of Late Holocene sediments of Sromowce (the Pieniny Mountains, Southern Poland). Folia Malacologica, 4: 7-24.

Alexandrowicz, S.W., 1993. Late Quaternary landslides at eastern periphery of the National Park of the Pieniny Mountains, Carpathians, Poland. Studia Geologica Polonica, 102 209-225.

Alexandrowicz, S.W., 2000. Malacofauna of Holocene cave sediments of the Cracow Upland (Poland). Folia Quaternaria, 71: 85-112.

Alexandrowicz, S.W., Alexandrowicz, W.P., 1995. Quaternary molluscan assemblages of the Polish Carpathians. Studia Geomorphologica Carpatho-Balcanica, 29: 41-54.

Alexandrowicz, S.W., Alexandrowicz, W.P., 2011. Analiza malakologiczna. Metody badań i interpretacji (in Polish). Rozprawy Wydziału Przyrodniczego PAU, 3: 5-302.

Alexandrowicz, S.W., Nadachowski, A., Rydlewski, J., Valde-Nowal, P., Wołoszyn, B.W., 1985. Subfossil fauna from a cave in the Sobczanski Gully (Pieniny Mts., Poland). Folia Quaternaria, 56: 57-78.

Alexandrowicz, S.W., Alexandrowicz, W.P., Krąpiec, M., Szychowska-Krapiec, E., 1997. Changes of the environment in southern Poland during the historic period (in Polish with English summary). Geologia, 23: 339-387.

Alexandrowicz, W.P., 1997. Malacofauna of Quaternary deposits and environmental changes of the Podhale Basin during the Late Glacial and Holocene (in Polish with English summary). Folia Quaternaria, 68: 7-132.

Alexandrowicz, W.P., 2000. Molluscann assemblages from cave and slope deposits of the Częstochowa Upland (Southern Poland). Folia Quaternaria, 71: 113-137.

Alexandrowicz, W.P., 2001. Molluscan assemblages from deposits filling small karst forms in the Tatra Mountains (Southern Poland). Acta Carstologica, 30: 125-142.

Alexandrowicz, W.P., 2004. Molluscan assemblabes of Late Glacial and Holocene calcareous tufas in Southern Poland. Folia Quaternaria, 75: 1-309.

Alexandrowicz, W.P., 2009. Malacofauna of Upper Holcene calcareous tufa in the Western Beskidy Mts (Southern Poland) (in Polish with English summary). Geologia, 35: 175-200.
Alexandrowicz, W.P., 2010. Molluscan assemblages of recent calcareous tufas in the Podhale Basin and Pieniny Mts (S. Poland). Folia Malacologica, 18: 99-112.

Alexandrowicz, W.P., 2013a. Molluscan assemblages in the deposits of landslide dammed lakes as indicators of late Holocene mass movements in the Polish Carpathians. Geomorphology, 180-181: 10-23.

Alexandrowicz, W.P., 2013b. Molluscan communities in Late Holocene fluvial deposits as indicator of human activity: a study in Podhale basin in South Poland. Ekológia (Bratislava), 32 : 111-125.

Alexandrowicz, W.P., Rudzka, D., 2006. Molluscan communities from cave and slope deposits of the liomestone rocky hills in the eastern part of Podhale Basin (Southern Poland). Folia Malacologica, 14: 191-201.

Alexandrowicz, W.P., Stworzewicz, E., 2003. Snails (Gastropoda). In: Obłazowa Cave - human activity, stratigraphy and palaeoenvironment (eds. P. Valde-Nowak, A. Nadachowski and T. Madeyska): 91-95. Institute of Archaeology and Ethnology Polish Academy of Sciences, Cracow.

Bradley, R.S., 2000. Past global changes and their significance for the future. Quaternary Science Review, 19: 391-402.

Briffa, K.R., 2000. Annual climate variability in the Holocene: interpreting the message of ancient trees. Quaternary Science Review, 19: 87-105.

Bronk Ramsey, C., 2003. OxCal Program v. 3.9. Radiocarbon Accelerator Unit, University of Oxford.

Chafetz, H.S., Folk, R.L., 1984. Travertines: depositional morphology and the bacterially controlled constituents. Journal of Sedimentary Petrology, 54: 289-316.

Füköh, L., 1995. History of the Hungarian Holocene mollusc fauna. Geojournal, 36: 255-259.

Gedda, B., 2001. Environmental and climatic aspects of the Early and Mid Holocene calcareous tufa and land mollusc fauna in southern Sweden. Lundqua Thesis, 45: 1-50.

Gedda, B., 2006. Terrestrial mollusc succession and stratigraphy of a Holocene calcareous tufa deposit from the Fyledalen valley, southern Sweden. The Holocene, 16: 137-147.

Goudie, A.S, Viles, H.A., Pentecost, A., 1993. The late-Holocene tufa decline in Europe. The Holocene, 3: 181-186.

Gradziński, M., Jach, R., Stworzewicz, E., 2001. Origin of calcite-cemented Holocene slope breccias from Długa Valley (the western Tatra Mountains). Annales Societatis Geologorum Poloniae, 71: 105-113.

Gradziński, M., Hercman, H., Jaśkiewicz, M., Szczurek, S., 2013. Holocene tufa in the Slovak Karst: facies, sedimentary environments and depositional history. Geological Quarterly, 57 (4): 769-788. 
Grove, J.M., Swistur, R., 1994. Glacial geological evidence for the Medieval Warm Period. Climate Change, 26: 143-169.

Hammer, Ø., Harper, D.A.T., Ryan, P.D., 2001. Past paleontological statistics software package for education and data analysis. Palaeontologica Electronica, 4: 1-9.

Hughes, M.K., Diaz, H.F., 1994. Was there a 'Medieval Warm Period' and if so, when and where? Climate Change, 26: 109-142.

Jäger, K.D., Ložek, V., 1968. Beobachtungen zur Geschichte der Karbonatdynamik in der Holozän Warmzeit. Československý Kras, 19: 7-20.

Jones, P.D., Mann, M.E., 2004. Climate over past millennia. Reviews of Geophysics, 42: 1-42.

Kołodziejski, J., Parczewski, M., Rydlewski, J., Valde-Nowak P., 1982. Dzieje osadnictwa w Pieninach od połowy XIV wieku (in Polish). Studia Naturae, B-30: 53-69.

Kostrakiewicz, L., 1982. Klimat (in Polish). Studia Naturae, B-30 403-421.

Ložek, V., 1959. Kvartérní travertiny Československa (in Czech). Časopis pro mineralogii a geologii 4: 85-90.

Ložek, V., 1961. Travertines. Prace Instytutu Geologicznego, 34 $81-86$.

Ložek, V., 1962. Pěnitcový převis Na klaku u Nitranskeho Pravna (in Czech). Krasový Sborník, 3: 31-46.

Ložek, V., 1963. Penovec - nový název pro sypké a polopevné travertiny (in Czech). Československý Kras, 14: 113-114.

Ložek, V., 1964. Quartärmollusken der Tschechoslovakei. Rozpravy Ústředního Ústavu Geologického, 31: 3-374.

Ložek, V., 1973. Příroda ve čtvrtohorách. Academia, Praha.

Matthews, J.A., Briffa, K.R., 2005. The 'Little Ice Age': re-evaluation of an evolving concept. Geografiska Annaler, 87 A: 17-36.

Mayewski, P.A., Rohling, E.E., Stager, J.C., Karlen, W., Maasch, K.A., Meeker, L.D., Meyerson, E.A., Gasse, F., van Kreveld, S., Holmgren, K., Lee-Thorp, J., Rosqvist, G., Rack, F., Staubwasser, M., Schneider, R.R., Steig, E.J., 2004. Holocene climate variability. Quaternary Research, 62: 243-255.

Meyrick, R.A., 2002. Holocene molluscan faunal history and environmental change at Kloster Mühle, Rheinland-Pfalz, western Germany. Journal of Quaternary Science, 18: 121-132.

Meyrick, R.A, Preece, R.C., 2001. Molluscan succesions from two Holocene tufas near Northampton, English Midlands. Journal of Biogeography, 28: 77-93.

Mikulski, J.S., 1974. Biologia wód śródlądowych (in Polish). Państwowe Wydawnictwo Naukowe, Warszawa.
Morisita, M., 1959. Measuring of interspecific association and similarity between communities. Memories of the Faculty of Science, Kyushu University, E-3: 65-80.

Obidowicz, A., 1990. Eine pollenanalytische und moorkundlische Studie zur Vegetationgeschichte des Podhale-Gebietes (West-Karpaten). Acta Palaeobotanica, 30: 147-219.

Pazdur, A., Pazdur, M.F., Starkel, L., Szulc, J., 1988a. Stable isotopes of the Holocene calcareous tufa in southern Poland as palaeoclimatic indicators. Quaternary Research, 30: 177-189.

Pazdur, A., Pazdur, M.F., Szulc, J., 1988b. Radiocarbon dating of Holocene calcareous tufa from south Poland. Radiocarbon, $\mathbf{3 0}$ : 133-146.

Pedley, H.M., 1990. Classification and environmental models of cool freshwater tufas. Sedimentary Geology, 68: 143-154.

Pedley, H.M., 2009. Tufas and travertines of the Mediterranean region: a testing ground for freshwater carbonate concepts and developments. Sedimentology, 56: 221-246.

Pentecost, A., 1991. Calcifications process in algae and cyanobacteria. In: Calcareous Algae and Stromatolites. (ed. R. Riding): 3-20. Springer.

Pentecost, A., 1995. The Quaternary travertine deposits of Europe and Asia Minor. Quaternary Science Reviews, 14: 1005-1028.

Pentecost, A., Viles, H.A., 1994. A review and reassessment of travertine classification. Géographie physique et Quaternaire, 48: 305-314.

Riedel, A., 1982. Ślimaki i pozostałe bezkregowce lądowe (in Polish). Studia Naturae, B-30: 292-310.

Riedel, A., 1988. Ślimaki lądowe (Gastropoda terrestia) (in Polish). Katalog Fauny Polski, 3: 3-316.

Smieja, A., Smieja-Król, B., 2007. Springs with active calcium carbonate precipitation in the Polish part of the Tatra Mountains. In: Karst and cryokarst (eds. A. Tyc and K. Stefaniak): 119-226. University of Silesia, Faculty of Earth Sciences, University of Wrocław, Zoological Institute, Sosnowiec-Wrocław.

Urbański, J., 1939. Mięczaki Pienin. Ze szczególnym uwzględnieniem polskiej części Parku Narodowego (in Polish). Prace Komisji Matematyczno-Przyrodniczej PTPN, 8-9: 1-240.

Žák, K., Ložek, V., Kadlec, J., Hladíková, J., Cílek, V., 2002. Climate-inducted changes in Holocene calcareous tufa formations, Bohemian Karst, Czech Republic. Quaternary International, 91: 137-152. 